\title{
PENGARUH PARTISIPASI PEMAKAI DAN DUKUNGAN MANAJEMEN \\ PUNCAK TERHADAP KESUKSESAN PENGEMBANGAN SISTEM INFORMASI AKUNTANSI SERTA DAMPAKNYA TERHADAP PROSES PENGAMBILAN KEPUTUSAN
}

\author{
Oleh: \\ Nasrizal \\ (Universitas Riau)
}

\begin{abstract}
The objective of this research was to examine empirically the influence of user participation and top management support on success of accounting information system development and its impact on decision making process. The analysis units were the hospital in Pekanbaru city. The election of sample is by using technique of probability sampling with method of simple random sampling. The statistical method used to test the hypothesises was path analysis with AMOS 20 program. The result shows that only the first hypothesis did not have a significant influence, while the others had a significant influence.
\end{abstract}

Keywords: user participation, top manajemen support, success of accounting information system development, and decision making process.

\section{Pendahuluan}

Pada dasarnya, hasil akhir dari sistem informasi yang dikembangkan, baik secara manual maupun berbasis komputer adalah adanya suatu sistem informasi yang sukses atau gagal.. Untuk mengukur kesuksesan atau kegagalan sistem informasi yang dikembangkan, suatu organisasi dapat menggunakan berbagai macam ukuran misalnya ukuran keuangan tradisional seperti Return on Investment (Rubin. 2004). Sedangkan untuk pemahaman yang lebih baik atas manfaat baik secara tangible maupun intangible atas sistem informasi, suatu organisisi dapat menggunakan metode seperti balanced scorecard (Kaplan dan Norton, 1996) dan benchmarking (Seddon et al.,2002). Selain itu beberapa peneliti telah membuat model-model untuk kesuksesan (DeLone dan McLean,1992) yang menekankan pada kebutuhan untuk mendapatkan metrik kesuksesan yang lebih baih dan lebih konsisten.

Kesuksesan ataupun kegagalan dari suatu sistem informasi yang dikembangkan, akan dipengaruhi oleh bebarapa faktor baik yang bersumber dari dalam maupun luar organisasi/perusahaan. Salah satu faktornya adalah partisipasi pemakai. Menurut Bodnar dan William (2010), dalam pengembangan sistem terutama dalam tahapan survei sistem, salah satu tujuan dalam survei sistem adalah membangun suatu hubungan kerjasama dengan pemakai sistem. Lebih jauh Bodnar dan William (2010) menjelaskan bahwa membangun hubungan kerjasama tersebut adalah suatu hal yang krusial, kesuksesan atau kegagalan dari proyek 
pengembangan sistem akan tergantung kepada besarnya kualitas hubungan antara tim pengembang dengan individu yang bekerja dalam sistem. Kemudian Romney dan Steinbart ((2012) menyatakan bahwa dalam tahapan analiasis sistem, studi kelayakan yang disiapkan merupakan input dari manajemen, akuntan dan pemakai (user).

Beberapa peneliti telah melakukan penelitian dengan melihat hubungan/pengaruh antara partisipasi pemakai terhadap pengembangan sistem. Ives dan M.H. Olson. (1984) mendapatkan bahwa pemakai mengungkapkan keselarasan kepuasan antara harapan seseorang dengan hasil yang diperoleh dari sistem sehubungan dengan partisipasi yang diberikannya selama pengembangan sistem. Kemudian Lawrence dan Graham (1993), hasil penelitiannya menyatakan bahwa kepuasan pemakai dalam pengembangaan sistem informasi dipengaruhi secara signifikan oleh partisipasi pemakai. Selanjutnya Hunton dan Kenneth (1994) hasil penelitianny menunjukkan bahwa kepuasan pemakai dalam pengembangan sistem informasi dipengaruhi secara signifikan oleh partisipasi pemakai.

Faktor lainnya yang juga berpengaruh terhadap pengembangan sistem adalah dukungan manajemen pnucak. Menurut Bodnar and William (2010), suatu yang krusial bahwa semua usaha pengembangan sistem memiliki dukungan dari manajemen puncak. Kemudian lebih jauh Bodnar and William (2010) mengatakan bahwa perhatian yang hati hati mesti diberikan kepada pengembangan suatu perencanaan dan strategi sistem, misalnya perencanaan mesti memasukkan dukungan dan persetujuan dari manajemen puncak. Romney dan Steinbart (2012) menyatakan bahwa dalam tahapan analiasi sistem studi kelayakan yang disiapkan merupakan input dari manajemen. Selain itu, Romney and Steinbart (2012) menyatakan untuk meminalkan reaksi perilaku yang kurang baik, seseorang mesti memahami mengapa adanya suatu perlawanan/penolakan/resistensi terhadap sistem tersebut, beberapa faktor penting meliputi antara lain adanya dukungan manajemen puncak.

Adapun penelitian tentang hal ini telah dilakukan oleh Raghunathan dan raghunathan, T. S. (1988). Hasil penelitiannya menyatakan bahwa dukungan manajemen puncak berpengaruh terhadap pengembangan sistem informasi. Peter, et al. (2008) menggunakan model-model kesuksesan sistem informasi. Ada enam dimensi utama kesuksesan sistem informasi, yakni kualitas sistem (system quality), kualitas inforrmasi (information quality), kualitas jasa (service quality), penggunaan system (system use), kepuasan pemakai (user satisfaction), dan manfaat bersih (net benefits).

Atas dasar latar belakang penelitian di atas, maka peneliti ingin meneliti dengan judul pengaruh partisipasi pemakai dan dukungan manajemen puncak kesuksesan pengembangan sistem informasi akuntansi serta dampaknya terhadap kualitas informasi. Pada penelitian ini, peneliti membatasi hanya satu dimensi kesuksesan saja yang digunakan yaitu dimensi kepuasan pemakai (user satisfaction) untuk mengukur kesuksesan atau kegagalan dalam pengembangan sistem informasi akuntansi. 


\section{Kajian Pustaka}

Adapun pengertian sistem informasi akuntansi menurut beberapa ahli adalah sebagai berikut: Wilkinson et al. (2000): Sistem informasi akuntansi adalah suatu struktur yang menyatu dalam entitas, misalnya perusahaan bisnis yang menggunakan sumber-sumber secara fisik dan komponen-komponen lainnya untuk menrubah data-data ekonomi menjadi informasi akuntansi, dengan tujuan memuaskan kebutuhan informasi dari berbagai macam pemakai. Menurut Jones and Dasaratha V. Rama (2006): Sistem informasi akuntansi adalah suatu sub system dari system informasi manajemen yang menyediakan informasi akuntansi dan keuangan maupun informasi lainnya yang diperolah dalam proses yang rutin dari transaksi akuntansi. Adapun menurut Moscove, et al. (1990): Sistem informasi akuntansi adalah suatu komponen organsisi yang mengakumulasikan, mengklasifikasikan, memproses, menganalisis dan mengkomunikasikan informasi keuangan yang relevan kepihak eksternal dan pihak internal dalam pengambilan keputusan. Romney dan Paul (2009): Sistem informasi akuntansi adalah suatu sistem yang mengumpulkan, mencatat, menyimpan dan memproses data untuk menyediakan onformasi untuk pembuat keputusan.

Bodnar dan Willliam (2010): Sistem informasi akuntansi adalah kumpulan dari sumber - sumber misalnya orang dan peralatan yang dirancang untuk merubah data keuangan dan data lainnya menjadi informasi. Jadi pada dasarnya sistem informasi akuntansi dapat diartikan sebagai suatu rerangka pengkoordinasian sumber daya (data, materials, equipment, supplies, personal, and fund) untuk mengkonversi input berupa data ekonomik menjadi keluaran berupa informasi keuangan yang digunakan untuk melaksanakan kegiatan bisnis suatu entitas, dan menyediakan informasi akuntansi bagi pihak-pihak yang berkepentingan.

Sebagaimana berbagai pengertian sistem informasi akuntansi yang dikemukakan di atas, tujuan utama dari sistem informasi akuntansi adalah untuk menyediankan informasi akuntansi ke berbagai macam pemakai (usesr), baik pemakai interanal maupun pemakai eksteranal. Berdasarkan tujuan utama tersebut, sistem inforamasi akuntansi memiliki tiga tujuan spesifik Wilkinson at al. (2000) yaitu: (1) Untuk mendukung operasi sehari-hari; (2) Untuk mendukung pengambilan keputusan oleh pembuat keputusan internal (internal decision maker); (3) Untuk memenuhi kewajiban terkait dengan pengelolaan perusahaan. (stewardship).

Menurut Wilkinson et al. (2000), komponen sistem informasi akuntansi meliputi: (1) Prosesor, merupakan suatu alat secara fisik yang digunakan untuk mengubah data menjadi informasi; (2) Database, meliputi semua data yang disimpan; (3) Prosedur, merupakan urutan tertentu dari langkah-langkah yang dilakukan dalam satu atau lebih fungsi akuntansi; (4) Alat input/output, alat masukan dan keluaran yang digunakan dalam sistem informasi akuntansi.

Sedangkan menurut Susanto (2008), komponen sistem informasi akuntansi meliputi: (1) Hardware, merupakan peralatan fisik yang dapat digunakan untuk mengumpulkan, memasukkan, memproses, menyimpan dan mengeluarkan hasil pengolaha data dalam bentuk informasi; (2) Software, 
merupakan kumpulan dari program-program yang digunakan untk menjalankan komputer. Tanpa software komputer tidak dapat melaksanakan fungsinya; (3) Brainware, merupakan sumber daya yang terlibat dalam pembuatan sistem informasi, pengumpulan dan pengolahan data, pendistribusian dan pemanfaaatan informasi yang dihasilkan oleh sistem informasi tersebut; (4) Prosedur, merupakan rangkaian aktivitas atau kegiatan yang dilakukan secara berulangulang dengan cara yang sama; (5) Database, merupakan kumpulan data-data yang tersimpan di dalam median penyimpanan di suatu perusahaan (arti luas) atau di dalam computer (arti sempit); (6) Teknologi jaringan komunikasi, atau telekomunikasi adalah penggunaan media elektronik atau cahaya untuk memindahkan data atau informasi dari satu lokasi ke satu atau beberapa lokasi lain yang berbeda.

Pengembangan sistem informasi sering disebut sebagai proses pengembangan sistem (System Development) adalah suatu aktivitas untuk menghasilkan sistem informasi berbasis komputer untuk menyelesaikan persoalan (problem) organisasi atau memanfaatkan kesempatan (opportunities) yang timbul.

Dalam pengembangan sistem, hal penting yang harus diperhatikan adalah manusia. Peranan manusia dalam sistem informasi sangat penting, karena perencanaan dan perancangan sistem informasi harus lebih jauh memperhatikan faktor manusia. Bentuk informasi yang ideal adalah suatu lingkungan kerja dimana mesin-mesin pengolah informasi yang berteknologi tinggi mampu mengerjakan tugas-tugas rutin menyediakan data yang dapat diakses untuk menghasilkan informasi yang dibutuhkan sehingga manajer penentu keputusan dapat bekerja tanpa dibebani tugas-tugas operasional menggali ide-ide kreatif dan menghasilkan keputusan yang tepat (Burch dan Grudnitski ,1989).

Sistem informasi akuntansi yang dikembangkan, pada penerapannya akan menghasilkan suatu sistem yang sukses atau gagal. Pada dasarnya perusahaan atau organisasi, tentu mengharapkan akan memperoleh suatu sistem informasi yang sesuai dengan harapan dan tujuannya. Suatu sistem informasi yang menemukan tujuannya, maka sistem informasi yang dkembangkan tersebut bisa dinyatakan sebagai suatu sistem yang sukses.

O’Brien (2010) menyatakan terdapat beberapa faktor yang menyebabkan kesuksesan atau kegagalan pengembangan sistem informasi dalam suatu organisasi/perusahaan. Faktor-faktor yang mempengaruhi kesuksesan tersebut antara lain karena adanya dukungan dari manajemen puncak dan partisipasi/ keterlibatan end-user (pemakai akhir)

Untuk mengukur kesuksesan sistem informasi yang dikembangkan, suatu organisasi dapat menggunakan berbagai macam ukuran misalnya ukuran keuangan tradisional seperti Return on Investment (Rubin. 2004). Sedangkan untuk pemahaman yang lebih baik atas manfaat baik secara tangible maupun intangible atas sistem informasi, suatu organisisi dapat menggunakan metode seperti balanced scorecard (Kaplan dan Norton, 1996) dan benchmarking (Seddon et al.,2002). Peneliti lainnya telah membuat model-model untuk kesuksesan (DeLone dan McLean,1992; Ballantine et al.,1996 dan Seddon,1997) yang menekankan pada kebutuhan untuk mendapatkan metrik kesuksesan yang lebih baih dan lebih konsisten. 
Partisipasi Pemakai adalah perilaku, pernyataan, dan aktivitas yang dilakukan pemakai selama proses pengembangan sistem informasi (Barki dan Hartwick, 1994) atau dengan kata lain tingkat keterlibatan individu dalam pengembangan sistem informasi. Banyak peneliti telah menyelidiki partisipasi pemakai. Mereka percaya bahwa partisipasi mempengaruhi kriteria kunci seperti kualitas sistem, kepuasan pengguna dan penggunaan sistem (Ives dan Olson 1984), partisipasi pemakai dalam proses pengembangan sistem mempunyai pengaruh positif terhadap kepuasan atas Computerize Based Information System (CBIS). McKeen dan James (1994) menyatakan partisipasi pengguna memiliki hubungan langsung dengan kepuasan pemakai. Pemakai atau penguna merupakan bagian yang tidak dapat dilepaskan dari keberhasilan penerapan suatu sistem atau teknologi.

Dukungan manajemen puncak adalah: keinginan dari manajemen puncak untuk menyediakan sumber-sumber yang diperlukan maupun hak untuk bertindak atau wewenang untuk kesuksesan proyek. (the willingness of the top management to provide the necessary resource and authority or power for project success) (Verhage,2009). Dalam tahapan pengembangan sistem informasi, manajemen puncak berupaya memberikan sebanyak mungkin informasi tentang sistim informasi yang sedang dikembangkan, dan ikut terlibat langsung dalam proses pengembangan sistem informasi. Pada tahap awal, manajemen puncak diharapkan secara aktif terlibat dalam menentukan perencanaan sistem informasi dan pada akhirnya manajemen puncak memberikan perhatian yang tinggi terhadap kinerja sistem informasi.

DeLone (1988), dan Choe (1996) telah melakukan peneltiaan secara empiris menguji bahwa dukungan manajemen puncak mempunyai pengaruh positif terhadap kenerja sistem informasi melalui berbagai macam kegiatan. Manajemen puncak bertanggung jawab atas penyediaan pedoman umum bagi kegiatan sistem informasi. Tingkat dukungan yang diberikan oleh manajemen puncak bagi sistem informasi organisasi dapat menjadi suatu faktor yang sangat penting dalam menentukan keberhasilan semua kegiatan yang berkaitan dengan sistem informasi (Raghunathan dan Raghunathan, 1988).

Menurut Mcleod dan George P. Schell (2008), Pengabilan keputusan (decision making) adalah tindakan memilih diantara berbagai alternatif solusi pemecahan masalah. Kemudian (Syafaruddin dan Anzizhan, 2004), mengatakan bahwa pengambilan keputusan adalah proses menentukan pilihan dari berbagai alternatif untuk menetapkan suatu tindakan dalam mencapai tujuan yang diinginkan Definisi ini mengandung substansi pokok di dalamnya, yaitu adanya proses (langkah-langkah), ada berbagai alternatif yang akan dipilih (bukan satu alternatif), ada ketetapan hati memilih satu pilihan, dan ada tujuan pengambilan keputusan. Pengambilan keputusan sebagai subsistem dari aktivitas manajemen muaranya untuk mendukung pencapaian tujuan secara efektif dan efisien. Jadi pengambilan keputusan merupakan tindakan pertama yang strategis dalam manajemen dimulai dari keputusan dalam perencanaan. Simon (1993) menegaskan bahwa pengambilan keputusan merupakan pekerjaan manajer meskipun bukan satu-satunya yang diutamakan.. Menurutnya pelatihan dan lolalitas pegawai dalam mendukung keputusan perlu dibangun. 
Menurut Simon (1993), instrumen yang sangat kuat manfaatnya dalam pengambilan keputusan adalah simulasi komputer dan pemikiran manusia. Yang dimaksud dengan konputer sebagai simulasi pemikiran manusia adalah sebagai berikut: (1) Setiap program komputer yang disusun dalam matriks adalah pemrosesan seperti semua yang digunakan oleh manusia. Ketika komputer menyusun matriks dapat membantu manusia mempermudah apa yang ingin dilakukannya. Dengan kata lain, ada beberapa program komputer dapat didemonstrasikan untuk melakukan sesuatu dalam bentuk penampilan kemanusiaan; (2) Komputer bekerja dengan cepat dan bekerja sangat menarik sesuai dengan program yang dibuat manusia sendiri; (3) Komputer manyusun progam sebagai penelitian kecerdasan buatan. Penyusunan program akan menjamin cara kerja komputer sebagai sesuatu yang didesain oleh pikiran manusia; (4) Komputer tidak hanya memecahkan masalah yang sukar bagi manusia untuk memecahkannya, tetapi kita dapat juga memperolehnya untuk memecahkan masalah dalam cara yang humanis.

Partisipasi pemakai dalam pengembangan sistem informasi akuntansi dipertimbangkan sebagai salah satu faktor penting yang mempengaruhi kesuksesan atau kegagalan pengembangan sistem. Menurut Jones dan Rama (2003), tujuan dari tahap analisis sistem dalam pengembangan sistem informasi adalah untuk dapat memahami sistem yang ada, berbagai tugas-tugas diindentifikasi, tim pengembangan sistem mengumpulkan informasi yang dibutuhkan, informasi mungkin dikumpulkan dari berbagai macam sumber yang meliputi dokumentasi yang ada, pengumpulan laporan yang sedang digunakan dan mewawancarai pemakai (user).. Kemudian Bodnar dan Hopwood (2010), dalam bukunya menyatakan bahwa dalam pengembangan sistem informasi pada tahap survei sistem memiliki empat tujuan, salah satu diantaranya adalah membangun hubungan kerjasama dengan pemakai sistem. Lebih jauh Bodnar dan Hopwood (2010) menyatakan bahwa kesuksesan atau kegagalan proyek pengembangan sistem akan tergantung kepada seberapa besar luas dan kualitas hubungan antara tim pengembang sistem dengan pemakai atau orang-orang yang bekerjasama dalam sistem.

Romney dan Steinbart (2012), menyatakan bahwa dalam pengembangan sistem para pemakai sistem informasi akuntansi hendaklah mengkomunikasikan kebutuhan informasi mereka ke pengembang sistem. Hal ini tentunya bertujuan untuk mendapatkan hasil pengembangan sistem yang lebih baik, dengan kata lain untuk mendapatkan kesuksesan dalam pengembangan sistem.

Secara empiris, partisipasi pemakai dalam pengembangan sistem informasi telah diteliti oleh peneliti. Menurut Edstrom (1977) dalam penelitiannya dengan judul pengaruh pemakai terhadap kesuksesan proyek manajemen information sistem (MIS), menyatakan bahwa keterlibatan pemakai berpengaruh secara signifikan terhadap kesukesan proyek manajemen information system. Hunton dan Kenneth (1994) dan Lawrence dan Graham (1993) hasil penelitiannya menunjukkan bahwa kepuasan pemakai dalam pengembangan sistem informasi dipengaruhi secara signifikan oleh partisipasi pemakai. Hasil penelitian Choe (1996) secara empris menyatakan bahwa ada hal yang berkorelasi secara positif 
dan signifikan dengan kinerja sistem informasi akuntansi, salah satu diantaranya adalah keterlibatan/partisiapsi pemakai.

Kemudian Ives dan Olson (1984) meneliti tentang keterlibatan pemakai dan kesuksesan sistem informasi manajemen,(MIS). Hasilnya menyatakan bahwa ada pengaruh keterlibatan pemakai terhadap kesuksesan system informasi manajemen. Selanjutnya Leitheiser dan Gerald, (1994), melakukan studi eksploratory lapangan mengenai partisipasi pemakai dalam pengembangan aplikasi yang sukses. Hasil studinya menyatakan bahwa keterlibatan pemakai telah menghasilkan suatu aplikasi yang sukses.

Partisispasi pemakai dalam pengembangan sistem informs yang sukses atau gagal akan berdampak kepada kepuasan pemakai pada sistem yang sedang dikembangkan. Menurut Swanson (1974) dalam penelitiannya dengan judul apresiasi dan keterlibatan menyatakan bahwa partisipasi pemakai dakan pengembangan sistem informasi yang sukses akan diapresiasi oleh pemakai.

Kemudian Ginzberg (1981) mendapatkan hasil penelitiannya bahwa adanya partisipasi pemakai dalam pengembangan sistem informasi yang sukses akan menyebabkan pemakai menjadi puas. Begitu juga Olson dan Ives (1982), menyatakan dalam peneltiannya bahwa partisispasi pemakai dalam pengembangan system informasi yang sukses akan memberikan kepuasan kepada pemakai.

Menurut Bodnar and William S. Hopwood, (2010), suatu yang krusial bahwa semua usaha pengembanan sistem memiliki dukungan dari manajemen puncak. Kemudian lebih jauh Bodnar and William S. Hopwood, (2010) mengatakan bahwa perhatian yang hati hati mesti diberikan kepada pengembangan suatu perencanaan dan strategi sistem, misalnya perencanaan mesti memasukkan dukungan dan persetujuan dari manajemen puncak.

Romney dan Steinbart (2012) menyatakan bahwa dalam tahapan analisis sistem studi kelayakan yang disiapkan merupakan input dari manajemen. Selain itu, Romney and Steinbart (2012) menyatakan untuk meminalkan reaksi perilaku yang kurang baik, seseorang mesti memahami mengapa adanya suatu perlawanan/penolakan/resistensi terhadap sistem tersebut, beberapa faktor penting meliputi antara lain adanya dukungan manajemen puncak.

Secara empiris, beberapa peneliti telah meniliti pengaruh dukunngan manajemen puncak terhadap pengembangan sistem informasi. antara lain, Raghunathan dan raghunathan, T. S. (1988). Hasil penelitiannya menyatakan bahwa dukungan manajemen puncak berpengaruh terhadap pengembangan sistem informasi.

Kesuksesan suatu sistem informasi akuntansi salah satu diantaranya dapat dilihat dari dimensi kualitas informasi (Peter et al, 2008), Oleh karena itu jika suatu sistem informasi bisa menghasilkan informasi yang berkualitas, maka dapat dikatakan bahwa sistem informasi yang dikembangkan tersebut sukses. Menurut Wilkinson et al. (2000), salah satu tujuan dari sistem informasi akuntansi adalah menghasilkan informasi yang berguna untuk mendukung pengambilan keputusan oleh pembuat keputusan internal (internal decision maker). Jika informasi yang dihasilkan dari sistem informasi mempunyai kualitas yang tinggi, maka akan menyebabkan proses pengambilan keputusan akan lebih baik. 
Kemudian Romney dan Steinbart (2006), menyatakakan bahwa sistem informasi akuntansi yang dirancang/dikembangkan dengan baik, akan dapat memperbaiki pengambalian keputusan. Ini dapat dikatakan bahwa perancangan/pengembangan sistem informasi yang baik ini merupakan suatu sistem informasi yang sukses, sehingga hal ini dapat memperbaiki pengambilan keputusan.

Secara empiris, Ponte dan Maria (2000), hasil penelitiannya menyatakan bahwa sistem informasi akuntansi dapat dipertimbangkan sebagai dukungan utama untuk memuaskan permintaan informasi selama proses pembuatan keputusan. Kemudian Ia menyatakan bahwa sistem informasi akuntansi dalam setiap tahapan operasionalnya diharapkan untuk dapat meningkatkan kuantitas dan kualitas informasi. Dengan bisanya suatu sistem informasi menghasilkan suatu informasi yang berkualitas, maka dapat dikatakan bahwa sistem informasi tersebut sukses dalam pengembangannya.

Kemudian, Sajady et al. (2008) secara empiris dalam penelitiannya menyatakan bahwa manfaat dari sistem informasi akuntansi dapat dievaluasi dengan melihat pengaruhnya terhadap proses pengambilan keputusan, kualitas informasi akuntansi, evaluasi kinerja, internal control dan kemudahan transaksi perusahaan.

Adapun hipotesis yang dibangun dalam penelitian ini adalah:

H1 : Partisipasi pemakai berpengaruh secara signifikan terhadap kesuksesan pengembangan sistem informasi akuntansi.

H2 : Dukungan manajemen puncak berpengaruh secara signifikan terhadap kesuksesan pengembangan sistem informasi akuntansi.

H3: Kesukesan pengembangan sistem informasi akuntansi berpengaruh secara signifikan terhadap proses pengambilan keputusan

H4: Partisipasi pemakai berpengaruh secara signifikan terhadap proses pengambilan keputusan melalui kesuksesan pengembangan sistem informasi akuntansi.

H5: Dukungan manajemen puncak berpengaruh secara signifikan terhadap proses pengamblan keputusan melalui kesuksesan pengembangan sistem informasi akuntansi.

\section{Metode Penelitian}

Adapun operasionalisasi dari masing-masing variabel adalah sebagai berikut: (1) Partisipasi Pemakai adalah perilaku, pernyataan, dan aktivitas yang dilakukan pemakai selama proses pengembangan sistem informasi (Barki dan Hartwick, 1994) atau dengan kata lain tingkat keterlibatan individu dalam pengembangan sistem informasi. Variabel ini diukur dengan tujuh skala Likert yang dijabarkan kedalam indicator dengan lima item pertanyaan; (2) Dukungan manajemen puncak adalah: the willingness of the top management to provide the necessary resource and authority or power for project success. (Verhage,2009). Variabel ini diukur dengan tujuh skala Likert yang dijabarkan kedalam indikator dengan enam item pertanyaan; (3) Kesuksesan pengembangan sistem informasi akuntansi (Y) didefinisikan sebagai sautu hal yang kompleks, saling ketergantungan dan sifat yang multidimensi dari kesuksesn sistem informasi itu 
sendiri. DeLone dan McLean (1992) mengidentifikasi ada 6 variabel atau komponen kesuksesan sistem informasi yang harus dimiliki oleh sistem informasi tersebut. Keenam komponen tersebut adalah: kualitas sistem, kualitas informasi, penggunaa, kepuasan sistem, pengaruh kepada orang (individual impact) dan pengaruh kepada organisasi (organizational impact).

Variabel ini diukur dengan tujuh skala Likert yang dijabarkan kedalam indikator dengan sepuluh item pertanyaan; (4) Proses pengambilan keputusan (Z), Pengambilan keputusan (decision making) adalah tindakan memilih diantara berbagai alternatif solusi pemecahan masalah. (Mcleod dan George P. Schell, 2008), Tindakan untuk memilih diantara berbagai alternatif solusi pemecahan masalah ini merupakan suatu proses yang terdiri dari berbagai tahap/langkah(step). Variabel ini diukur dengan tujuh skala Likert yang dijabarkan kedalam indikator dengan enam item pertanyaan.

Populasi dalam penelitian ini adalah semua rumah sakit yang berada di wialyah di Kotamadya Pekanbaru Riau, baik itu rumah sakit pemerintah maupun rumah sakit swasta. Teknik sampling yang digunakan dalam penelitian ini adalah probability sampling, dengan menggunakan simple random sampling.

Pengujian hipotesis dalam penelitian ini menggunakan analisis jalur (path analysis) melalui progam AMOS 20. Analisis jalur meupakan pengembangan lebih lanjut dari analisis regresi berganda dan bivariate. Analisi jalur ingin menguji persamaan regresi yang melibatkan beberapa variabel eksogen dan endogen sekaligus sehingga mungkingkan pengujian terhadap variabel mediating/intervening atau variabel antara. Disamping itu analisis jalur juga dapat mengukur hubungan langsung antara variabel dalam model maupun hubungan tidak langsung antar variabel dalam model.

\section{Hasil Penelitian dan Pembahasan}

Hasil pengujian yang dilakukan dengan program AMOS dapat dilihat pada tabel berikut ini:

\section{Tabel 1}

\section{Hasil Pengujian Hipotesis Pertama}

\begin{tabular}{|l|l|l|l|l|l|r|l|}
\hline & & & Estimate & S.E. & C.R. & P & Keterangan \\
\hline KPem & $<---$ & PP &, 076 &, 230 &, 330 &, 741 & H1 ditolak \\
\hline
\end{tabular}

Sumber: data olahan program AMOS

Berdasarkan hasil pengujian hipotesis pertama sebagaimana yang ditunjukkan pada tabel di atas, diperoleh hasil secara empiris nilai signifikansi $\mathrm{p}$ (probabilitas) sebesar 0,741, dan nilai critical ratio (C.R) sebesar 0,330. Nilai probabilitas (p) lebih tinggi dari nilai alpha 5\% $(0,05)$, dan nilai critical rasio (C.R) lebih rendah dari nilai t pada alpha 5\% yakni 1,96. Maka dapat disimpulkan bahwa secara emipiris hipotesis pertama ditolak. Ini berarti tidak ada pengaruh langsung antara partisipasi pemakai dengan kesuksesan pengembangan sistem informasi akuntansi yang dilihat dari dimensi kepuasan pemakai. Dengan demikian hipotesis pertama ditolak. 
Hasil pengujian yang dilakukan dengan program AMOS dapat dilihat pada tabel berikut ini:

Tabel 2

Hasil Pengujian Hipotesis Kedua

\begin{tabular}{|l|l|l|l|l|l|c|c|}
\hline & & & Estimate & S.E. & C.R. & P & Keterangan \\
\hline KPem & $<---$ & DMP &, 600 &, 251 & 2,390 &, 017 & H2 diterima \\
\hline
\end{tabular}

Sumber: data olahan program AMOS

Berdasarkan hasil pengujian hipotesis kedua sebagaimana yang ditunjukkan pada tabel di atas, diperoleh hasil secara empiris nilai signifikansi $\mathrm{p}$ (probabilitas) sebesar 0,017, dan nilai critical ratio (C.R) sebesar 2,390. Nilai probabilitas (p) lebih rendah dari nilai alpha 5\% $(0,05)$, dan nilai critical rasio (C.R) lebih tinggi dari nilai t pada alpha 5\% yakni 1,96. Maka dapat disimpulkan bahwa secara empiris hipotesis kedua diterima. Ini berarti ada pengaruh langsung antara dukungan manajemen puncak dengan kesuksesan pengembangan sistem informasi akuntansi yang dilihat dari dimensi kepuasan pemakai. Dengan demikian hipotesis kedua diterima.

Hasil pengujian yang dilakukan dengan program AMOS dapat dilihat pada tabel berikut ini:

\section{Tabel 3}

Hasil Pengujian Hipotesis Ketiga

\begin{tabular}{|c|c|c|c|c|c|c|c|}
\hline & & & Estimate & S.E. & C.R. & P & Keterangan \\
\hline PPK & $<---$ & KPem &, 414 &, 092 & 4,490 & $* * *$ & H3 diterima \\
\hline
\end{tabular}

Sumber: data olahan program AMOS

Berdasarkan hasil pengujian hipotesis ketiga sebagaimana yang ditunjukkan pada tabel di atas, diperoleh hasil secara empiris nilai signifikansi $\mathrm{p}$ (probabilitas) sebesar 0,000, dan nilai critical ratio (C.R) sebesar 4,490. Nilai probabilitas (p) lebih rendah dari nilai alpha $5 \%(0,05)$, dan nilai critical rasio (C.R) lebih tinggi dari nilai t pada alpha 5\% yakni 1,96. Maka dapat disimpulkan bahwa secara empiris hipotesis ketiga diterima. Ini berarti ada pengaruh langsung antara kepuasan pemakai yang merupakan dimensi dari kesuksesan pengembangan sistem informasi akuntansi terhadap proses pengambilan keputusan. Dengan demikian hipotesis ketiga diterima.

Adapun hasil pengujian untuk melihat pengaruh langsung partisipasi pemakai terhadap proses pengambilan keputusan yang dilakukan dengan program AMOS, dapat dilihat pada tabel berikut ini:

\section{Tabel 4}

Hasil Pengujian Pengaruh Langsung

Partisipasi Pemakai terhadap Proses Pengambilan Keputusan

\begin{tabular}{|c|c|c|c|c|c|c|c|}
\hline & & & Estimate & S.E. & C.R. & P & Keterangan \\
\hline PPK & $<---$ & PP &, 333 &, 139 & 2,397 &, 017 & $\begin{array}{c}\text { Ada Pengaruh } \\
\text { Langsung }\end{array}$ \\
\hline
\end{tabular}

Sumber: data olahan program AMOS

82 | Jurnal Riset Akuntansi dan Keuangan Vol.1 | No.1 | 2013 
Berdasarkan hasil pengujian pada tabel di atas, diperoleh hasil bahwa ada pengaruh langsung antara partisipasi pemakai terhadap proses pengambilan keputusan. Hal ini dibuktikan dengan nilai signifikansi $\mathrm{p}$ (probabilitas) sebesar $0,017 \%$, yang lebih rendah dari nilai alpha $0,05 \%$. dan nilai critical rasio (C.R) sebesar 2,397 \% yang lebih tinggi dari nilai t pada alpha 5\% yakni 1,96.

Sedangkan hasil pengujian hipotesis keempat yang dilakukan dengan program AMOS dapat dilihat pada tabel berikut ini:

\section{Tabel 5}

Hasil Pengujian Hipotesis keempat

\begin{tabular}{|l|c|c|c|c|}
\hline & $\begin{array}{c}\text { Pengaruh } \\
\text { Langsung }\end{array}$ & $\begin{array}{c}\text { Pengaruh } \\
\text { tidak } \\
\text { langsung }\end{array}$ & $\begin{array}{c}\text { Total } \\
\text { Pengaruh }\end{array}$ & Keterangan \\
\hline $\begin{array}{l}\text { Pengaruh PP terhadap } \\
\text { PPK melalui KPem }\end{array}$ & 0,359 & $\begin{array}{c}0,061 \times 0,556 \\
=0,033\end{array}$ & 0,392 & H4 diterima \\
\hline
\end{tabular}

Sumber: data olahan sendiri

Berdasarkan hasil pengujian hipotesis keempat sebagaimana yang ditunjukkan pada tabel di atas, diperoleh hasil secara empiris bahwa ada tambahan atau kontribusi dari variabel intervening kepuasan pemakai yang merupakan dimensi dari kesuksesan pengembangan sistem informasi akuntansi dalam memediasi pengaruh partisipasi pemakai terhadap proses pengambilan keputusan. Jika dilihat dari pengaruh langsung antara partisipasi pemakai terhadap proses pengambilan keputusan nilainya sebesar 0,359. Sedangkan pengaruh tidak langsungnya sebesar 0,033 . Apabila pengaruh langsung ditambahkan dengan pengaruh tidak langsung, maka nilainya menjadi 0,392. Nilai total pengaruh ini (pengaruh langsung + pengaruh tidak langsung) leibh besar dibandingkan dengan nilai pengaruh langsung. Oleh karena itu dapat dikatakan bahwa ada pengaruh partisipasi pemakai terhadap proses pengambilan keputusan melalaui kesuksesan pengembangan sistem informasi akuntansi yang merupakan dimensi dari kepuasan pemakai, dengan demikian hipotesis keempat diterima.

Adapun hasil pengujian untuk melihat pengaruh langsung dukungan manajemen puncak pemakai terhadap proses pengambilan keputusan yang dilakukan dengan program AMOS, dapat dilihat pada tabel berikut ini:

\section{Tabel 6}

\section{Hasil Pengujian Pengaruh Langsung}

Dukungan Manajemen Puncak terhadap Proses Pengambailan Keputusan

\begin{tabular}{|l|l|l|l|l|l|l|c|}
\hline & & & Estimate & S.E. & C.R. & P & Keterangan \\
\hline PPK & $<---$ & DMP &, 137 &, 135 & 1,021 &, 307 & $\begin{array}{c}\text { Tidak ada } \\
\text { Pengaruh } \\
\text { Langsung }\end{array}$ \\
\hline
\end{tabular}

Sumber: data olahan program AMOS

Berdasarkan hasil pengujian pada tabel di atas, diperoleh hasil bahwa ada pengaruh langsung antara dukungan manajemen puncak terhadap proses 
pengambilan keputusan. Hal ini dibuktikan dengan nilai signifikansi $p$ (probabilitas) sebesar 0,307 \%., yang lebih tinggi dari nilai alpha 0,05\%. dan nilai critical rasio (C.R) sebesar 1,021\% yang lebih rendah dari nilai t pada alpha 5\% yakni 1,96 .

Sedangkan hasil pengujian hipotesis kelima yang dilakukan dengan program AMOS dapat dilihat pada tabel berikut ini:

Tabel 7

Hasil Pengujian Hipotesis kelima

\begin{tabular}{|l|c|c|c|l|}
\hline & $\begin{array}{c}\text { Pengaruh } \\
\text { Langsung }\end{array}$ & $\begin{array}{c}\text { Pengaruh } \\
\text { tidak langsung }\end{array}$ & $\begin{array}{c}\text { Total } \\
\text { Pengaruh }\end{array}$ & Keterangan \\
\hline $\begin{array}{l}\text { Pengaruh DMP } \\
\text { terhadap PPK melalui } \\
\text { KPem }\end{array}$ & 0,134 & $\begin{array}{c}0,435 \times 0,556= \\
0,242\end{array}$ & 0,376 & H5 diterima \\
\hline
\end{tabular}

Sumber: data olahan sendiri

Berdasarkan hasil pengujian hipotesis kelima sebagaimana yang ditunjukkan pada tabel di atas, diperoleh hasil secara empiris bahwa ada tambahan atau kontribusi dari variabel intervening kesuksesan pengembangan sistem informasi akuntansi dalam memediasi pengaruh dukungan manajemen puncak terhadap porses pengambilan keputusan. Jika dilihat dari pengaruh langsung antara dukungan manajemen puncak terhadap proses pengambilan keputusan nilainya sebesar 0,134, sedangkan pengaruh tidak langsungnya sebesar 0,242, . Apabila pengaruh langsung ditambahkan dengan pengaruh tidak langsung, maka nilainya menjadi 0,376 . Nilai toal pengaruh ini (pengaruh langsung + pengaruh tidak langsung) lebih besar dibandingkan dengan pengaruh langsung, oleh karena itu dapat dikatakan bahwa ada peningkatan pengaruh dukungan manajemen puncak terhadap proses pengambilan keputusan melaui pengaruh kesuksesan pengembangan sistem informasi akuntansi, dengan demikian hipotesis kelima diterima.

\section{Simpulan}

Dari hasil pengujian hipotesis secara empiris yang telah dilakukan untuk melihat pengaruh partisispasi pemakai dan dukungan manajemen puncak terhadap kesuksesan pengembangan sistem informasi akuntansi dengan dimensi kepuasan pemakai, dan sekaligus melihat dampaknya terhadap proses pengambilan keputusan, maka dapat disimpulkan sebagai berikut:

1. Padal pengujian hipotesis pertama, memberikan bukti empris bahwa tidak ada pengaruh yang signifikan antara partisipasi pemakai terhadap kesuksesan pengembangan sistem informasi akuntansi. Hal ini ditunjukkan dengan nilai signifikansi probilitas (p) 0,741 yang lebih tinggi dari 0,05 atau nilai critical ratio (C.R) 0,330 yang lebih rendah dari nilai t pada alpha 5\% yakni 1,96.

2. Padal pengujian hipotesis kedua, memberikan bukti empris bahwa ada pengaruh yang signifikan antara dukungan manajemen puncak terhadap kesuksesan pengembangan sistem informasi akuntansi. Hal ini ditunjukkan 
dengan nilai signifikansi probilitas (p) 0,017 yang lebih redanh dari 0,05 atau nilai critical ratio (C.R) 2,390 yang lebih tinggi dari nilai t pada alpha $5 \%$ yakni 1,96.

3. Padal pengujian hipotesis ketiga, memberikan bukti empris bahwa ada pengaruh yang signifikan antara kesuksesan pengembangan sistem informasi akuntansi terhadap proses pengambilan keputusan. Hal ini ditunjukkan dengan nilai signifikansi probilitas (p) 0,000 yang lebih redanh dari 0,05 atau nilai critical ratio (C.R) 4,490 yang lebih tinggi dari nilai t pada alpha 5\% yakni $1,96$.

4. Padal pengujian hipotesis keempat, memberikan bukti empris bahwa ada pengaruh yang signifikan antara partisipasi pemakai terhadap proses pengambilan keputusan melalui variabel intervening kesuksesan pengembangan sistem informasi akuntansi Hal ini ditunjukkan dengan adanaya tambahan nilai atau kontrbibusi dari variabel intervening dalam meningkatkan pengaruh partisipasi pemakai terhadap proses pengambilan keputusan.

5. Padal pengujian hipotesis kelima, memberikan bukti empris bahwa ada pengaruh yang signifikan antara dukungan manajemen puncak terhadap proses pengambilan keputusan melalui variabel intervening kesuksesan pengembangan sistem informasi akuntansi Hal ini ditunjukkan dengan adanaya tambahan nilai atau kontrbibusi dari variabel intervening dalam meningkatkan pengaruh dukungan manajemen puncak terhadap proses pengambilan keputusan.

\section{Saran}

1. Dilihat dari hasil pengujian hipotesis pertama menunjukkan bahwa tidak ada pengaruh yang signfikan antara partisipasi pemakai terhadap kepuasan pemakai yang merupakan dimensi dari kesuksesan pengembangan sistem informasi akuntansi. Menurut dugaan penulis hal ini mungkin disebablkan oleh adanya pembiasan persepsi responden dalam menanggapi pertanyaan yang ada pada kuesioner. Oleh karena itu disarankan peneliti selanjuntya untuk bisa mengontrol pengisian kuesioner dengan cara mendampingi langsung responden pada saat pengisian kuesioner, dengan demikian peneliti dapat memberikan arahan dan maksud dari masing-masing pertanyaan kuesioner.para pemakai yang ada di rumah sakit- rumah sakit Dugaan lainnya karena sampel dalam perusahaan ini mencampuradukkan antara rumah sakit pemerintah dengan rumah sakit swasta, maka diduga bahwa pengembangan sistem informasi akuntansi yang ada di rumah sakit swasta mengabaikan adanya partisipasi pemakai dalam pengembangan sistem informasi akuntansinya, hal ini sesuatu yang biasa terjadi dimana manejemn tidak bisa membuat keputusan sendiri akan tetapi lebih banyak mengikuti apa yang diinginkan oleh pemilik (owner), dengan arti kata keputusan yang dbuat oleh pihak manajemen lebih cendrung mengikuti kemauan pemilik.

2. Karena adanya keterbatasan sampel/data, pengujian hipotesis yang dilakukan masih mencampurkan antara rumah sakit pemerintah dengan rumah sakit 
swasta, .dan juga belum membedakan antara rumah sakit yang berskala besar dengan yang berskala kecil. Oleh kerena itu peneliti selanjutnya disarankan untuk dapat memisahkan antara rumah sakit pemerintah dengan rumah sakit swasta dan juga membedakan antara rumah sakit yang berskala besar dengan yang berskala kecil. Perbedaan ukuran rumah sakit ini bisa diangkat menjadi satu variabel moderating yang bisa diteliti untuk penetlitan selanjutnya.

\section{Daftar Pustaka}

Ballantine J, Bonner M, Levy M, Martin AIM and Powell PL ,1996, The 3-D model of information systems success: the search for the dependent variable continues. Information Resources Management Journal 9(4), 514.

Barki, H., dan Hartwic J.,. 1994 "Measuring User Participation, User Involvement, And User Attitude". MIS quartery. Maret. page.59-62

Bodnar George H., and William S. Hopwood, 2010, Accounting Information System, Tenth Edition, Pearson Education, Inc.

Burch, John., dan Grudnitski. 1989. "Information Systems Theory and Practise". John Wiley \& Sons, Inc. New York, NY USA, fifth edition

Choe, Jong-Min. 1996. "The Relationship Among Performance of Accounting Information System, Influence Factors, And Evolution Level of Information System". Jurnal of Management Information System. Spring. Vol 12, No. 4

DeLone WH and McLean ER ,1992, Information systems success: the quest for the dependent variable. Information Systems Research 3(1), 60-95.

Edstrom, Anders. 1977." User Influence and Success of MIS Projects: A Contingency Approach, Human Relation. 30,7 hal 589-607

Ginzberg, M.J., 1981. "Early Diagnosis of Implementation Failure: Promising Result and Unanswered Questions". Management science. April. Vol. 27, No. 4

Hunton, J.E., dan H.P., Kenneth. 1994. "A Framework for Investigating Involvement Strategies In Accounting Information System Development". Behavioral research in accounting. Vol. 6

Ives, B., dan M.H. Olson. 1984. "User Involvment and MIS Success: A review of research". Management science. May. Hal. 586-603

Jones, Frederick L. and Dasaratha V. Rama, 2006, Accounting Information System: A Business Process Approach, Second Edition, Thomson South Western, page 5

Kaplan RS, and Norton DP ,1996, Translating Strategy into Action: The Balanced Scorecard. Harvard Business School Press, Boston.

Lawrence, M., dan L. Graham. 1993. "Exploring Individual User Satisfaction Within-Led Development". MIS quarterly. June

Leitheiser, Robertn dan Gerald M Hoffman. 1994. "User Participation in Successful Aplication Development: An Exploratory Field Study" Journal of Information Technolgy Management. Vol 5 No. 2 
McKeen D.J., G. Tor, dan C.W. James. 1994. "The Relatiobship of User Participation and User Satisfaction: An Investigation of four Contingency Factors". MIS Quarterly. December

McLeod, Raymond Jr, dan George P. Schell, 2008, Management Information Systems, Tenth edition, Pearson Prentice Hall.

Moscove Stephen A., Mark G. Simkin, and Nancy A. Bagranoff, 1990, Accounting Information System: Concept and Practice for Effective Decision Making, Fourth Edition, John Wiley \& Sons.

Olson, Margrethe H. dan Ives, Blake. 1982. "User Involvement in System Design: An Empirical Test of Alternative Approach. Information and Management. 4. Hal. 183-195.

O’Brian, James A, 2010, Introduction to Information System, Edisi 15

Petter, Stacie, William DeLone and Ephraim McLean, 2008, European Journal of Information Systems Measuring information systems success:models, dimensions, measures, and interrelationships, 17, page 236-263

Romney Marshall B., and Paul John Steinbart, 2009, Accounting Information Systems, Eleventh Edition, Pearson Prentice Hall.

Rubin, H ,2004, Into the light. In CIO Magazine. http://www.cio.com.au/ index.php/id;1718970659, accessed on July 2004.

Sajady, M. Dastgir dan Hashem Nejad, 2008, International Journal of Information Science \& Technology, Vol.6, No.2 July/Desember.

Seddon P, Graeser V and Wilcocks LP ,2002, Measuring organizational IS effectiveness: an overview and update of senior management perspectives. The DATA BASE for Advances in Information Systems 33(2), 11-28

Seddon PB ,1997, A respecification and extension of the DeLone and McLean model of IS success. Information Systems Research 8(3),240-253.

Susanto, Azhar, 2008, Sistem Informasi Akuntansi, Edisi pertama, Lingga Jaya.

Swanson, E. Burton. 1974. " Management Information System: Aplication and Involvement. Management Science, Oktober. Hal. 178-188

Syafaruddin dan Azizhan (2004), Sistem Pengambilan Keputusan Pendidikan, Grasindo, hal. 94.

Verhage.L.,2009. Management methodologie voor de implementatie Van Enterprise systems, page 83. (Slevin and Pinto 1987).

Wilkinson, Joseph W., Michael J. Cerullo, Vasant Raval, and Bernard Wong On Wing, 2000, Accounting Information System: Essential Concepts and Application, Fourth Edition, John Wiley and Sons, Inc. 